\title{
STUDIES ON POLIOMYELITIS VIRUS. CONCENTRATION AND PURIFICATION OF THE VIRUS
}

\author{
By A. POLSON \\ C.S.I.R. and U.C.T. Virus Research Unit, Department of Pathology, \\ University of Cape Town (South Africa) \\ AND J. W. F. HAMPTON \\ Laboratories of the Poliomyelitis Research Foundation, \\ Johannesburg (South Africa)

\section{INTRODUCTION}

The perfection of tissue culture methods has led to the development of a formalintreated vaccine against poliomyelitis which has been widely used. The method generally employed for the preparation of this vaccine involves the treatment of tissue culture fluids, containing not less than $10^{6}$ tissue culture infective doses (T.C.I.D. ${ }_{50}$ ) of virus per ml. with formalin, at a concentration of 1/1000 to 1/4000.

The unfortunate occurrence of cases of poliomyelitis which could be attributed to residual live virus in one or two batches of vaccine led to the introduction of very strict regulations governing the method of manufacture and of carefully prescribed tests for safety and potency. It is apparent that under the conditions of manufacture at present generally employed, a critical concentration of formaldehyde is required to render the vaccine safe for human administration and at the same time to retain its immunizing power.

The bulk of antigen present per unit volume in a vaccine prepared from tissue culture fluid containing $10^{6}$ T.C.I.D ${ }_{50}$ per $\mathrm{ml}$. of virus only $30 \mathrm{~m} \mu$ in diameter is extremely small. Facilities available to us made it possible to prepare virus concentrates containing 1000-10,000 times as much virus per ml. as the vaccine so far used. With such concentrates we have been able to undertake experiments to determine whether less critical, but more reliable, methods could be employed for the inactivation of virus without rendering it antigenically inert.

This paper describes the methods employed in the preparation of concentrated virus suspensions.

\section{MATERIALS AND METHODS}

Tissue culture fluids containing the Brunhilde strain (Type 1), Collins (Type 2), and Leon (Type 3), which had been rejected for use in vaccine were used in these experiments. These were produced by the conventional methods involving virus growth on trypsinized monkey kidney cells in culture medium ' 199 '.

Cellophane sausage-casings (The Visking Corporation, Chicago) of about 2 in. diameter when inflated, were fitted with rubber bungs at one end into which a rubber-capped glass tube was inserted for convenience of filling and emptying under sterile conditions. It is advantageous to offset the position of the filling 
tube close to one side of the bung for the removal of air bubbles and for the complete emptying of the casing. The filling tube should be long enough to enable its cap to be dipped into boiling water before and after filling or emptying; the other end of the casing is sealed in the usual way. The use of long lengths of casings, holding up to $10 \mathrm{l}$., is to be recommended as this minimizes the number of filling operations. After sterilization by steaming, these casings were filled by siphoning directly from the $10 \mathrm{l}$. bottles in which the material was contained. When filled and capped the casings were placed on a grid of $\frac{1}{2}$ in. steel mesh having a number of table fans playing on its surface and placed about $3 \mathrm{ft}$. above a number of domestic $1 \mathrm{~kW}$. heaters fitted with reflectors. In these circumstances the rate of evaporation was sufficient to keep the temperature of the fluids at $23^{\circ} \mathrm{C}$. or less, where the relative humidity was $50-55 \%$. By this means a concentration to $1 / 10$ vol. can be obtained in about $9 \mathrm{hr}$. Such a period of evaporation was followed by dialysis overnight at $5^{\circ}$ against a volume of distilled water equal to the original volume of material taken. The casings were then either refilled, or their contents transferred into a smaller number of casings, and the pervaporation and dialysis cycle repeated until a volume of about $200 \mathrm{ml}$. was reached. At this stage cell debris and other insoluble material was centrifuged out at 2000 r.p.m. for 45 min. Pervaporation was continued until $1 / 1000$ th of the original volume was obtained. This was dialysed finally against $\mathrm{M} / 15$ phosphate buffer of $\mathrm{pH} 7 \cdot 0$, centrifuged at 10,000 r.p.m. for 10 min., ampouled in air, shell-frozen and stored in a dry ice cabinet at about $-40^{\circ} \mathrm{C}$.

\section{RESULTS}

A pilot batch of 51 . of Type 1 virus having an initial titre of $10^{-6.3}$ T.C.I.D. ${ }_{50}$ was processed in this manner to yield $50 \mathrm{ml}$. of concentrate having a titre of $10^{-8.9}$ T.C.I.D. ${ }_{50}$. This was further concentrated by ultra-centrifugation at 30,000 r.p.m. for $90 \mathrm{~min}$. with resuspension of the pellets in $5 \mathrm{ml}$. phosphate buffer at $\mathrm{pH} 7 \cdot 0$ to give a colourless, opalescent fluid representing a thousand-fold concentration and having a titre of $10^{-10.6}$ T.C.I.D. ${ }_{50}$ per $\mathrm{ml}$. Taking into consideration the volume of the pellet, it can be assumed that the concentration of active virus in the pellets was in excess of $10^{12}$ infective units per $\mathrm{ml}$. This showed quantitative recovery of live virus (within the limits of experimental errors). Concentration of larger quantities of virus suspensions was therefore carried out. In this way $62 \cdot 11$. of Type 1, 55 l. of Type 2, and 49.7 l. of Type 3 virus were concentrated to 76 , 60 and $70 \mathrm{ml}$. respectively, in 4 to 5 cyc. of pervaporation, and without ultracentrifugation. Penicillin and streptomycin were added in each cycle. During the final clarification at 10,000 r.p.m. a considerable amount of fatty material separated in the supernatant. As the removal of this had been found to give enhanced titres, a sample of each concentrate was extracted by shaking once with an equal volume of ether in the cold before assay.

These concentrated virus suspensions (subsequently referred to as 'crude concentrates') were dark viscous fluids of protein concentration approximately $\mathbf{4} \cdot \mathbf{4 4} \%$ (by refractometer). The concentrations of virus (by tissue culture assay) 
were: Type $1,10^{10.0}$; Type $2,10^{9.8}$ and Type $3,10^{9.5}$ tissue culture infective doses per ml.

After purification for electron microscopy as previously described (Polson \& Selzer, 1954; Hampton, Polson \& Selzer, 1955) these concentrates gave photographs typical of pure virus suspensions. It is intended to describe their particle sizes and some other properties at a later date.

\section{SUMMARY}

For the purpose of determining the immunogenic potency of polio virus, relatively large amounts of concentrated virus material were prepared which had titres of the order of $10^{10}$ T.C.I.D. ${ }_{50}$ per ml. These were obtained by pervaporating large quantities of tissue culture fluid containing approximately $10^{6.5}$ T.C.I.D. ${ }_{50}$ per $\mathrm{ml}$.

We wish to acknowledge the valuable assistance received from $\operatorname{Dr} P$. D. Winter and his staff, of the Poliomyelitis Research Foundation, in carrying out the tissue culture titrations of these materials.

\section{REFERENCES}

Hampton, J. W. F., Polson, A. \& Selzer, Golda (1955). Biochim. biophys. Acta, $17,592$. Polson, A. \& Selzer, G. (1954). Biochim. biophys. Acta, 14, 67.

(MS. received for publication 15. х. 56) 